\title{
XXXV. On the hydrometer
}

\section{William Speer Esq.}

To cite this article: William Speer Esq. (1802) XXXV. On the hydrometer, Philosophical Magazine Series 1, 14:55, 229-237, DOI: 10.1080/14786440208676188

To link to this article: http://dx.doi.org/10.1080/14786440208676188

$$
\text { 曲 Published online: } 18 \text { May } 2009 .
$$

Submit your article to this journal 준

LII Article views: 3

Q View related articles $\asymp$ 
backwards, but muft have been as reprefented in the figure, the points thrown out by the fpiral twilt on each fice:-in this pofition they might have anfwered in firiking down fnall animals, or in detaching thell-fith from the bottoms of rivers, or even in afcending the banks.

In the elephant the orbit of the eye is fituated at C, whereas in the correfponding part at $\mathrm{C}$ in the manmoth is a large mafs of bone, fo that the eve mult have been elfewhere: to afcertain where, we muft wait until we receive the cranium lately difcovered on the Obio. The cheek of the elephant is formed of two bones; but in the mammoth, befides other variations, there is but one bone. The whole figure of the under-jaw differs moft remarkably; firt in the length of the condyles or arms from $\mathrm{E}$ to $\mathrm{B}$ : in the mammoth it is fhort and angular; but in the elephant DE B forms a femicircular line, and at D it is long and pointed.

This thort reference is fufficient to direct the attention of thofe who wifl to examine them more critically; when they may remark feveral other characters fufficiently interefting.

XXXV. On the Hydrometer. By WILliam Spexr, Efq. Supervifor and Affoyer of Spirits int the Port of Dublin.

[Concludad fron p. 162.]

I SHALL now proceed to explain Mr. Gilpin's tables, in order to demonftrate their ufe, and the ufe of my additional columus. The firt I caunot do better than in the words of Sir Charles Blagden himfelf:

"Tables for reducing the quantities by weight, in any mixture of pure fpirit and water, to thole by meafure; and for determining the proportion, by meafure, of each of the two fubftances in fuch mixtures, by Mr. George Gilpin, clerk to the Royal society, communicated by Sir Charles Blagden :

"T Thefe tables are founded on the experiments, of which the refults werc given in the Report and Supplementary Report on the beft Nethod of proportioning the Excife on Spirituous Liquors. They are computed for every degree of heat, from $30^{\circ}$ to $80^{\circ}$, and for the addition of fubtraction of every one part in a hundred of water or fpirit; but as the experiments themfelves were made only to erery fifth deguce of heat, and every five in the hundied of water or fpirit, 1 : intermediate places are filled up by interpolation in the $y^{\circ}$. manner, with allowance for fecosd differences. 
"Every table confifts of eight columns, and there are two tables for every degree of heat. In the firit column of the firft of the two tables are given the proportions of fpirit and water by weight, 100 parts of fpirit being taken as the conftant number, to which additions are made fucceffively of one part of water, from I to 99 inclufively: the firft column in the fecond table has 100 parts of water for the conftant number, with the parts of fpirit decreafing fucceffively by unity, from Ioo to 1 inclufively.

"It muft be obferved, that each of thefe tables, occupying one page, is divided in the middle for adapting it more conveniently' to the fize of the paper; but the whole of each page is to be confidered as one continued table. The fecond column of all the tables gives the fpecific gravities of the correfponding mixtures of fpirit and water in the firft column, taken from the table of f pecific gravities in the Supplementary Report, the intermediate fpaces being filled up by interpolation. In the third column, 100 parts by meafure of pure fpirit, at the temperature marked at the top of every feparate table, is affumed as the conftant fandard number, to which the refpective quantities of water by meafure, at the fame temperature, are to be proportioned in the next column.

"The fourth column, therefore, contains the proportion of water, by meafure, to 100 meafures of fpirit, anfwering to the proportions by weight in the fame horizontal line of the firft column. The fifth column thows the number of parts which the quantities of fpirit and water, contained in the third and fourth columns, would meafure when the mixture has been completed; that is, the bulk of the whole mixture after the concentration or mutual penetration has fully taken place. The fixth column, deduced from the three preceding ones, gives the effects of that concentration, or how much fmaller the volume of the whole mixture is, than it would be if there was no fuch principle as the mutual penetration. The feventh column thows the quantity of pure fpirit by meafure, at the temperature in the table, contained in an hundred meafures of the mixture laid down in the ffth column."

From this account it will be feen, that every mixture of pure fpirit and water poffible to be made, is analyfed fo clearly at every temperature, as to render it a matter of no great difficulty to demonftrate, at a given temperature, all the gradations of ftrength which the hydrometer hould indicate. The mode in which this has been done I thall now explain.

The table which Mr. Gilpin has calculated for the temperature of 55 , is that which I have chofen, conceiving it, 
for fcveral reafons, to be the moft convenient. And as a reference to it becomes neceffary, I have annexed this, with the additional columns to it, by which the hedrometer indications of ftrength are regularly deduced from the fpecific gravity of the fpirit at this temperature *.

In order to explain the manner in which I have calculated thefe additional columns, I conceive the eafieft mode will be by an example.

It being underftood by the trade that the fpecific gravity of proof fpirit at this temperature (55) is 922, I look at the table for this fpecific gravity, and I find that it is a mixture of pure fpirit and water, in the following proportions, viz. Ioo parts of the former to $8 \mathrm{I}$ of the latter (both by weight), but that by meafure it is made by mixing 100 gallons of pure fpirit with 66 gallons 99 parts of water. I then find that the diminution of bulk, by penetration, on the mixture by meafure, (that by weigbt being unneceffary to attend to in bringing out the refult, ) is 4 gallons 57 parts, as, inftead of producing 166 gallons 99 parts, there will be only 162 gallons 42 parts. I find next, that this mixture contains per cent. of pure fpirit 6I gallons 57 parts.

Thefe being the proportions in the ftandard of proof, to which every other gradation of Atrength is relative, the Rule of Three demonftrates this relation in a manner requiring to be explained by another example. Suppofe a fpirituous liquor is produced to afcertain the hydrometer indication; on weighing it in a phial adapted to this purpofe, I find that at the temperature of 55 , its fpecilic gravity is 848 ; by looking into the table I perceive that this contains per cent. 93.18 of pure fpirit. I then try how much more than proof this is by lubtracting $6 \mathrm{I}^{\circ} 57$ (the quantity which proof contains), and I find that this has a redundance of pure fpirit, amounting to $3 \mathrm{I} \cdot 6 \mathrm{I}$.

Therefore, as 100 gallons of pure fpirit require 66 gallons 99 parts of water to reduce it to proof, the redundant $31 \cdot 6 \mathrm{I}$ will require $2 \mathrm{I}^{\cdot 17}$. Add thefe, and from the amount 52,78 the diminution of bulk by penetration is to be deducted, which, by the ratio in proof fpirit being 1.44 , the refult finally comes out that this fpirit is $5 \mathrm{I}$ gallons and 34 parts (about one-third) over hudrometer proof. The under proofs require lefs calculation, the excefs of water per cent. over the proportion which proof contains being all thai is required.

* It may perhaps be necentary to oblerve here, that a reference to this table is not required in the ufe of the hydiumeter I have contructed, further than to try whetiner it be crrreet. 
Thefe examples are, I hope, fufficient to explain this table. The ufes to which it is applicable, are, that as it afjords firft an unequivocal flandard for every gradation of Jtrength, an hydrometer can be graduated on a certain principle; and, fecondly, the errors of thofe that are graduated otherwife may be difcovered by it, and we fhall no longer be obliged to rely on a mere affertion, that the inftrument is correct, nothing more being required than to compare the fpecific gravity of the firit with the indication of ftrength which it has demonftrated.

On confidering how far it might be practicable to fimplify the hydrometer, I perceived that the makers of thefe inftruments had fallen into two errors, which had very confiderably increafed the neceffity for thofe complex additions with which they are incumbered.

Firft, conceiving that the inftrument was to be valued in proportion as it was capable of making minute difcriminations, (or of its fenfibility as it is called,) they have, by attempts to increafe this beyond thofe limits required either in revenue or in commerce, deftroyed its fimplicity.

In the conftruction of this inftrument, the proportion of the ftem to the ball is an important confideration: if the former be ton large, the inftrument will not be fufficiently fenfible; and hould it, on the contrary, be too fmall, the number of gradations of ftrength it is capable of indicating will proportionably be diminifhed.

Thofe who have conftructed moft of the hydrometers now in ufe, have run into the latter error ; the ftem being diminifhed to a fize which rendered it neceffary to have recourfe to complex additions to fupply the place of this injudicious and unneceffary wafte of the fimple and proper power of the inftrument.

From a great variety of experiments to afcertain the proper proportion between the ball and ftem, I was finally fatisfied that the latter would admit of fuch enlargement as to be ren dered capable of meafuring upwards of 66 gradations or per centages of ftrength, without any weight; and this fo clearly and diftinctly, as to convince me that its fenfibility and accuracy were Rill fully fufficient.

The fecond error alluded to has arifen from an attempt to extend the power of the intrument beyond thofe limits, which, with propriety, and confiftently with its fimplicity, could be effected.

An hydrometer being a counterpoife to afcertain the weight of a fpirituous liquor, may, with propriety, be compared to a 6 
pair of fcales *, of which there are various $f \approx e s$ and $d c f c r i p-$ tions, to anfwer different purpojes, by which means their smplicity is uniformly preferved.

On the contrary, it has erroneoully been conceived, that an hydrometer would be imperfeet that did not, by one means or anotber, afcertain the fpecific gravity of all liquids at their various temperatures : the fimple power of every inftrument of this kind being confined within certain limits, this could not be effected without additional complications of various kinds to thofe which were added, to increafe its fenfibility, fome of which are certainly ingenious, but, I conceive, highly unfit for the purpofe of revente.

Should this ingenuity be exercifed on a pair of fcales, which it would be proper to ufe in weighing a portion of eight or ten pounds, and by complex additions render them fufficiently fenfible to afcertain a few grains or fraction of a grain, or fo extenled in their power as to weigh 100 pounds, is it not evident that the fimplicity of the balance, which is its great recommendation, would be deftroyed?

That which led to the conftruction which I fnally fixed on, was firft a quadrangular ftem, from which I had four temperatures, viz. $35,45,55$, and 65 ; and the intermediate degrees I managed with four fmall weights on the top of the ftem, each ferving for two degrees of temperature. The inftrument having been graduated with thefe on, if the temperature hould be two degrees higher than the fcale, I removed one weight, in order to lighten the inftrument equal to the decreafe of fpecific gravity; if four degrees, I removed two weights; if $f 2 x$ degrees, I removed three weights; and if eight degrees, $I$ removed the fourth; and two degrees more brought me to a new fale, or fide of the ftem : by this means the inftrument would accord with the variations arifing from temperature, fo far as at moft to be but one degree different from it. It was adjufted at every tenth degree of temperature.

This was evidently a confiderable progrefs towards the object I was in purfuit of, as it not only remedied the great defect of inattention to temperature which took place in the Irifh hydrometer, but, in a great meafure, the various defects of the Englith revenue bydrometer, as, notwith ftanding the weights were reduced from $3^{6}$ to 4 , it accorded nearly with

* The name of the inftrument, which in ftrictnefs fhould be areometer, (hydrometer being an infrument for weighing water), demonftrates this to be the principle on which it acts; therefore in France it is called pefe liqueur, and by fome Englih writers, a water-poife. 
the various temperatures, and indicated 66 gradations of ftrength. I perceived, therefore, that the principle would anfwer, but that it could be improved ftill further; and after. various efforts $I$ at length fixed on that conftruction, of which I thall now beg leave to give a defcription.

This new hydrometer is made of hard brafs: the ball is thaped in the form of a pear, being nearly two inches in diameter at its greateft dimenfion, and two inches and a quarter in length: the lower ftem meafures one inch and a half, and is in thape a prifn, each fide meafuring one-eighth of an inch : to the lower end of this a round weight is fixed, the diameter of which is feven-eighths of an inch. The upper ftem is in length five inches and a half, and is an ostagon, each fide being fomewhat lefs than an eighth of an inch wide: each of thefe fides is graduated for a temperature engraved on the top, the loweft being 35 , the fecond 40 , and fo increafing by five until it reaches 70 . The zero, or proof point, is marked $\Theta$, and the gradations of ftrength (numbered at every fourth) amount to fixty-fix, and thofe fo clearly diftinet, that at the over-proofs they will adnit of a fub-divifion, and by that means indicate a half per cent. Thefe divifions are not at equal diftances; an error which takes place in the prefent Irifh and feveral of the old hydrometers, but widen in proportion as the fpecific gravity of the fpirit diminithes; and, being graduated with fpirits of known ftrengths at every four per cent., the intermediate per centages are adjufted by interpolation.

To prevent any error which might arife from taking the indication of frength from the wrong fide of the ftem, an index is applied on the top of it, with an opening to thow the figures which point out the temperature. This index, which applies merely to the purpole here mentioned, may be removed lower to any part of the ftem, but above the furface of the liquor, without affecting the accuracy of the inftrument, as neither its weight nor dimenfion is changed; and being. of a different colour from the ftem (fanguined fteel) it forms a contraft with it, and, as it were, points to the indication fought for, by which every danger of error in this refpect is removed.

Although this is the only ufe of the index, when the temperature thall be found one of thofe eight marked on the ftem, yet it is neceffary that the inftrument fhall accord with the four intermediate degrees between each of the adjoining fides: for this purpofe one of two other indexes of different weights arc occafionally fubftituted for the firft one, in order to lighten 
the inftrument fo as to accord with the decreafe of gravity which takes place in the fpirit by the increafe of temperature. Therefore the manner of ufing the inftrument is as follows :

Suppofing the temperature to be 50 , nothing further is required but to place the index No. 1 (each being marked fo as eafily to be diftinguifhed) on the fide marked 50 , and immerfe the inftrument, which at once thows the Arength. Should the temperature be 51 or 52 , inftead of index No. 1 , ufe that marked No. 2: fhould it be 53 or 54 , ufe index No. 3 : the inftument having been adjufted with thefe two auxiliary indexes, in the one cafe at a temperature of $5^{1}$, and in the other $53 \frac{1}{2}$, thefe four intermediate temperatures are fo accorded to, as to be either the actual one, or within balf a degree of it. And they apply in all cafes, to the four intermediate degrees of temperature, and no other appendage required to enable the inftrument, in this plain and fimple manner, to meafure fixty-fix gradations of thrength with an accuracy which, it is prefumed, is fully fufficient for either revenue or commerce *. No weight requiring different immerfions to find out that which is the proper one; no temperature omitted to create doubts, or falle indications of ftrength; no fraction in the per centage to operate either againft the revenue or the merchant; no gradation of ftrength left unafcertained or determined by conjecture; no doubt remaining as to the correct $\mathrm{ft}$ :ength of all the various gradations; and no fecond infpection and fubfequent combination to be made, requiring the aid of, and liable to the errors of, a fliding rule.

The following is a table for graduating hydrometers on a certain and invariable principle, thowing from the fpecific gravity of the fpirit at the temperature 55 , what the hycrometer indication of ftrength thould be of every poffible mixture of pure fpirit (or alcohol) and water, from the former down to proof fpirit.-N. B. This table is calculated on the fuppojition that the ftandard of proof is 922 , temperature 55 .

* Even this half degree of temperature may be obtained by holding the jar containing the fpirit for a few moments in the hand. 


\begin{tabular}{|c|c|c|c|c|c|c|c|c|c|c|}
\hline 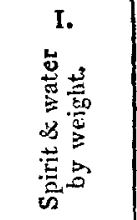 & 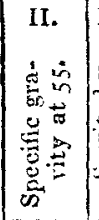 & 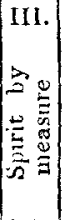 & 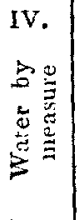 & 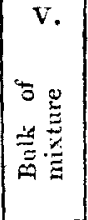 & 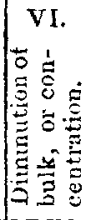 & 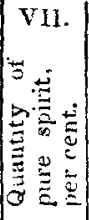 & 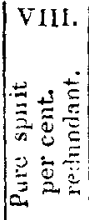 & 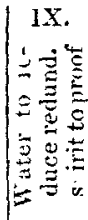 & 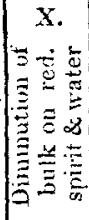 & 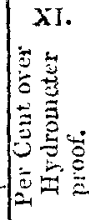 \\
\hline \multicolumn{11}{|l|}{ Sp. + W. } \\
\hline $100+0$ & $\mid \begin{array}{l}82736 \\
82967 \\
83192 \\
83412 \\
83626\end{array}$ & 100 & $\begin{array}{l}0,83 \\
1,65 \\
2,43 \\
3,31\end{array}$ & $\mid \begin{array}{l}100,00 \\
100,72 \\
101,44 \\
102,16 \\
102,80\end{array}$ & $\begin{array}{l}0,11 \\
0,21 \\
0,32 \\
0,42\end{array}$ & $\begin{array}{c}100,00 \\
99,29 \\
96,30 \\
97,80 \\
97,19\end{array}$ & $\begin{array}{l}3^{8,43} \\
37,7^{2} \\
37,01 \\
3^{6,31} \\
3,3,62\end{array}$ & $\begin{array}{l}2,5,74 \\
2,7,26 \\
24,79 \\
2,1,32 \\
2,3,86\end{array}$ & $\begin{array}{l}1,75 \\
1,7,2 \\
1,69 \\
1,6,5 \\
1,62\end{array}$ & $\begin{array}{l}62,42 \\
61,26 \\
60,11 \\
53,98 \\
57,66\end{array}$ \\
\hline $100+$ & $\mid \begin{array}{l}83834 \\
84037 \\
84235 \\
64429 \\
84618\end{array}$ & & $\begin{array}{l}4,93 \\
4,16 \\
5,79 \\
6,62 \\
7,44\end{array}$ & $\begin{array}{l}103,62 \\
104,30 \\
105,10 \\
10,3,84 \\
106,58\end{array}$ & $\begin{array}{l}0,51 \\
0,60 \\
0,69 \\
0,78 \\
0,86\end{array}$ & $\begin{array}{l}96,50 \\
9,5,82 \\
95,15 \\
94,49 \\
9,3,83 \\
\end{array}$ & $\begin{array}{l}34,0,3 \\
34,25 \\
33,5^{8} \\
32,92 \\
32,20\end{array}$ & $\begin{array}{l}2,3,39 \\
22,9.1 \\
22,49 \\
22,05 \\
21,61\end{array}$ & $\begin{array}{l}1,50 \\
1,50 \\
1,53 \\
1,50 \\
1,47 \\
\end{array}$ & $\begin{array}{l}56,-33 \\
5,7,63 \\
54,54 \\
53,47 \\
52,40\end{array}$ \\
\hline $\begin{array}{r}100+10 \\
11 \\
12 \\
13 \\
14\end{array}$ & $\begin{array}{l}84802 \\
84982 \\
85158 \\
85330 \\
835499\end{array}$ & & $\begin{array}{r}8,27 \\
9 \cdot 10 \\
9,92 \\
10,75 \\
11,5\end{array}$ & $\begin{array}{l}10,3,32 \\
108,0 \\
108,81 \\
109,56 \\
110,32\end{array}$ & $\begin{array}{l}0,9,5 \\
1,03 \\
1,11 \\
1,10 \\
1,20\end{array}$ & $\begin{array}{l}9.3,18 \\
92,-4 \\
91,90 \\
91,27 \\
90,65\end{array}$ & $\begin{array}{l}31,61 \\
30,07 \\
30,03 \\
20,-0 \\
29,00\end{array}$ & $\begin{array}{l}21,17 \\
20,74 \\
20,31 \\
19,80 \\
10,47\end{array}$ & $\begin{array}{l}1,44 \\
1,41 \\
1,30 \\
1,3,3 \\
1,32\end{array}$ & $\mid \begin{array}{l}51,34 \\
50,30 \\
40,26 \\
4,26 \\
47,2,3\end{array}$ \\
\hline $\begin{array}{r}100+15 \\
16 \\
17 \\
18 \\
19\end{array}$ & 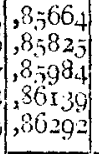 & & $\begin{array}{l}12,41 \\
13,2, \\
14,0 \\
14,89 \\
15,-1\end{array}$ & $\begin{array}{l}111,07 \\
111,02 \\
112,38 \\
113,34 \\
114,09\end{array}$ & $\begin{array}{l}1,34 \\
1,41 \\
1,48 \\
1,, 55 \\
1,62\end{array}$ & $\begin{array}{l}90,0,3 \\
30,43 \\
88, ; 3 \\
88,2: 3 \\
87,64\end{array}$ & $\begin{array}{l}328,46 \\
27,86 \\
27,26 \\
2,26,06 \\
2,26,07 \\
1,2,07\end{array}$ & $\left\{\begin{array}{l}10,06 \\
18,66 \\
18,26 \\
17,06 \\
17,46\end{array}\right.$ & $\begin{array}{l}1,30 \\
1,27 \\
1,24 \\
1,21 \\
1,19\end{array}$ & $\begin{array}{l}46,22 \\
4,2,25 \\
44,23 \\
4,3,30 \\
1,2,34\end{array}$ \\
\hline $\begin{array}{r}100+20 \\
21 \\
22 \\
23 \\
24\end{array}$ & 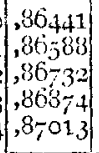 & & $\begin{array}{l}16,54 \\
17,37 \\
13,19 \\
10,02 \\
19,3\end{array}$ & $\begin{array}{l}114,96 \\
11,5,62 \\
116,36 \\
117,11 \\
117,90\end{array}$ & $\begin{array}{l}1,63 \\
1,75 \\
1,61 \\
1,88 \\
1,95\end{array}$ & $\begin{array}{l}8,, 06 \\
86,49 \\
8,4,3 \\
3, ;, 37 \\
84,8=\end{array}$ & & 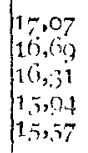 & $\begin{array}{l}1,16 \\
1,13 \\
1,11 \\
1,08 \\
1,06\end{array}$ & $\begin{array}{l}41,40 \\
40,48 \\
39,60 \\
38,60 \\
37,-6\end{array}$ \\
\hline $\begin{array}{r}100+25 \\
26 \\
27 \\
28 \\
29\end{array}$ & $\mid \begin{array}{l}37150 \\
, 87284 \\
, 87413 \\
8-8744 \\
876-1\end{array}$ & 100 & $\begin{array}{l}20,68 \\
21,50 \\
22,33 \\
2,3,10 \\
2.3,98\end{array}$ & $\begin{array}{l}118,6- \\
110,43 \\
120,20 \\
120,97 \\
121,74\end{array}$ & $\begin{array}{l}2,01 \\
2,07 \\
2,13 \\
2,19 \\
2,24\end{array}$ & $\begin{array}{l}84,27 \\
83,7 \\
83,10 \\
82,60 \\
82,14\end{array}$ & 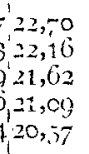 & $\begin{array}{l}1,5,20 \\
14,44 \\
14,48 \\
14,12 \\
1,3,7\end{array}$ & $\begin{array}{l}1,03 \\
1,01 \\
1,98 \\
0,90 \\
0,93\end{array}$ & $\mid \begin{array}{l}36,87 \\
35,09 \\
35,12 \\
34,25 \\
33,41\end{array}$ \\
\hline $\begin{array}{r}100+30 \\
31 \\
32 \\
33 \\
34\end{array}$ & 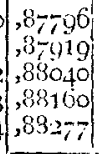 & & $\begin{array}{l}2+, 81 \\
2,6,61 \\
26,40 \\
2-29 \\
26,12\end{array}$ & $\begin{array}{l}122,51 \\
123,28 \\
123,0 \\
124,0,0 \\
124,62 \\
125,59 \\
1\end{array}$ & $\begin{array}{l}2,30 \\
2,36 \\
2,41 \\
2,47 \\
2,73\end{array}$ & $\begin{array}{l}81,63 \\
81,1,2 \\
30,6,2 \\
30,12 \\
79,6,3\end{array}$ & $\begin{array}{l}320,00 \\
19,50 \\
10,00 \\
10,50 \\
118,00\end{array}$ & $\begin{array}{l}1,3,4,3 \\
1,3,01 \\
12,-6 \\
12,42 \\
1,2,09\end{array}$ & $\begin{array}{l}0,01 \\
0,00 \\
0,8= \\
0,84 \\
0,82\end{array}$ & $\left\{\begin{array}{l}32,53 \\
31,7,5 \\
30,94 \\
30,13 \\
20,33\end{array}\right.$ \\
\hline $\begin{array}{r}100+35 \\
63 \\
37 \\
38 \\
39 \\
\end{array}$ & $\mid \begin{array}{l}38303 \\
, 38,307 \\
, 88619 \\
, 38-29 \\
, 83833 \\
\end{array}$ & & $\begin{array}{l}28,0,5 \\
29,77 \\
30,60 \\
31,43 \\
32,25\end{array}$ & & $\begin{array}{l}2,50 \\
2,64 \\
2,70 \\
2,75 \\
2,80 \\
\end{array}$ & $\begin{array}{l}7,1,14 \\
73,616 \\
78,13 \\
7,7,7 \\
77,25\end{array}$ & $\begin{array}{l}17,57 \\
17,09 \\
3,16,61 \\
16,1,4 \\
10,68\end{array}$ & $\begin{array}{l}11,7 \\
11,44 \\
11,12 \\
10,01 \\
10,50\end{array}$ & $\begin{array}{l}0,80 \\
0,78 \\
0,76 \\
0,74 \\
0,71 \\
\end{array}$ & $\left\{\begin{array}{l}28,34 \\
27,75 \\
26,97 \\
26,21 \\
2,747\end{array}\right.$ \\
\hline $\begin{array}{r}100+40 \\
41 \\
42 \\
43 \\
44\end{array}$ & 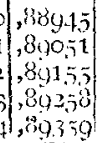 & & $\begin{array}{l}33,08 \\
3,3,01 \\
34,75 \\
3,50 \\
30,30\end{array}$ & $\begin{array}{l}31.30,2.3 \\
11.31,60 \\
+1.31,-, \\
1.32,6 \\
91,3,3,33\end{array}$ & $\begin{array}{l}2,8,5 \\
2,91 \\
2,90 \\
3,01 \\
3,06\end{array}$ & $\begin{array}{l}76,79 \\
56,33 \\
75,30 \\
75,41 \\
75,00\end{array}$ & $\begin{array}{l}1,1,22 \\
1,4,-6 \\
014,31 \\
11,3,38 \\
13,43\end{array}$ & $\mid \begin{array}{c}10,19 \\
9,83 \\
9,5^{8} \\
9,-9 \\
9,40\end{array}$ & $\begin{array}{l}0,69 \\
0,67 \\
0,65 \\
0,63 \\
0,61\end{array}$ & $\mid \begin{array}{l}24,72 \\
2 ; 3,97 \\
2 ; 3,24 \\
22,54 \\
21,711\end{array}$ \\
\hline
\end{tabular}




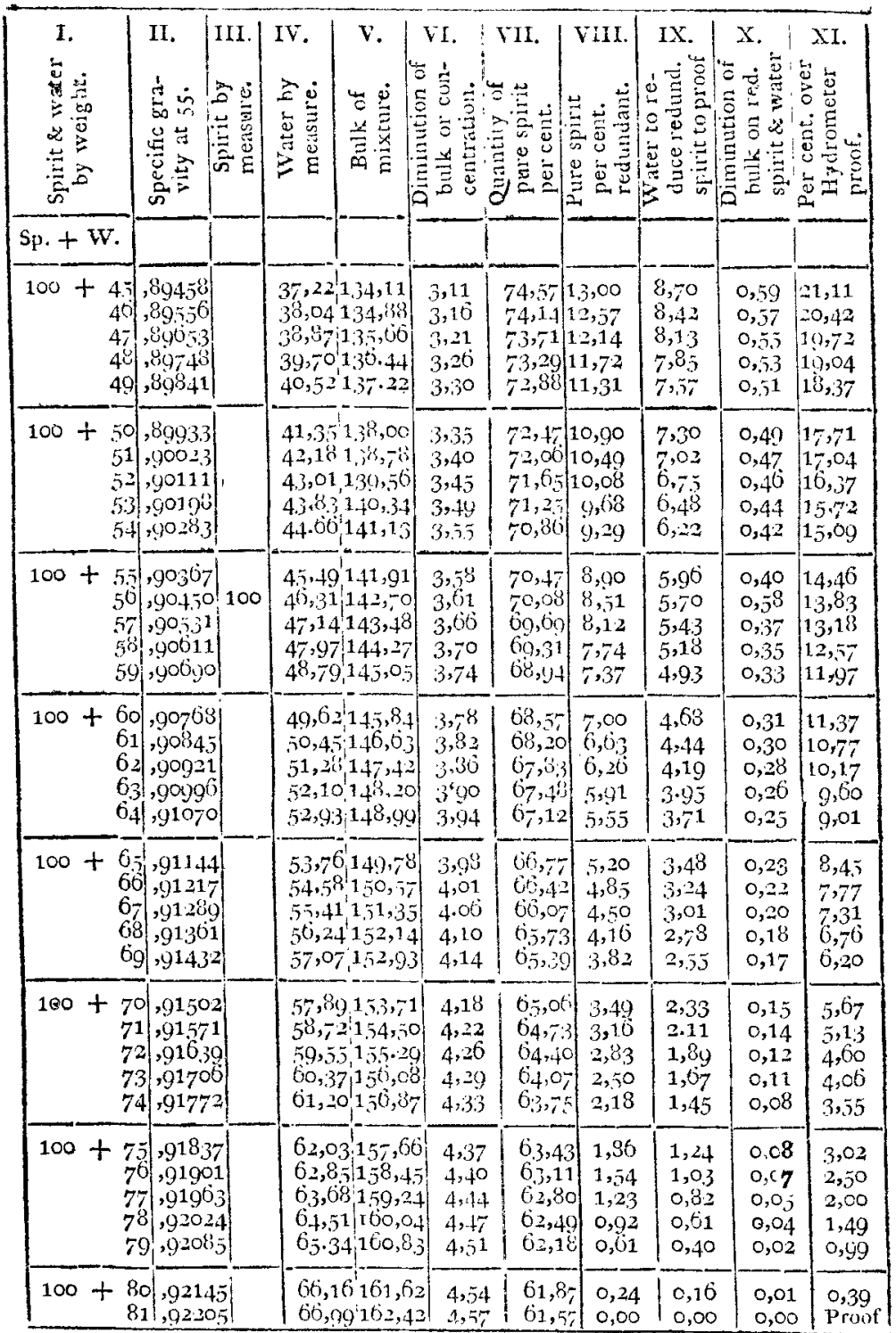

N. B. When this Table fhall be finally calculated, the fradtions in the fecond aid laft column are to be rendered into whole numbers. 